Going digital: Changing the game of danish publishing

Hjarvard, Stig; Helles, Rasmus

Published in:

Northern Lights. Film \&amp; Media Studies Yearbook

DOI:

10.1386/nl.13.1.49_1

Publication date:

2015

Document version

Peer reviewed version

Document license:

CC BY-NC-ND

Citation for published version (APA):

Hjarvard, S., \& Helles, R. (2015). Going digital: Changing the game of danish publishing. Northern Lights. Film \&amp; Media Studies Yearbook, 13(1), 49-64. https://doi.org/10.1386/nl.13.1.49_1 
Northern Lights, Volume 13 (c) 2015 Intellect Ltd Article. Post-print. Original available here: http://www.ingentaconnect.com/content/intellect/nl/2015/00000013/00000001/art00004

\title{
Going digital: Changing the game of Danish publishing
}

\author{
Stig Hjarvard and Rasmus Helles \\ University of Copenhagen
}

\begin{abstract}
This article aims to analyse current transformations in the Danish book publishing industry in light of the convergence between the book and the broader media culture. We focus on changing relationships between actors (publishing houses, bookstores, etc.) in the trade book's circuit of production, distribution and consumption. The development of the e-book challenges established routines of publishers, which must cope with new groups of actors in both the production and distribution of their products as well as new ways for readers to access and consume books. Methodologically, the study is based on qualitative interviews with key organizational actors in the Danish publishing industry and document studies of available industry information and statistics. On a theoretical level, the project combines organizational theory and institutional perspectives of mediatization in order to address the question of how the introduction of new media reconfigures old media industries. In particular, we focus on the interplay between book business actors' perceptions of digital technology, the changing market conditions, and the possibilities this entails for them.

The convergence between the book and other media is enabled by 'institutional entrepreneurs', who import perceptions and practices from other media industries into book publishing. These changes at the organizational level also affect the balance between 'market' and 'cathedral' in the book publishing industry as a whole. The distinction between 'brownfield' and 'greenfield' development allows us to understand why existing players in the book market generally try to adapt to digital technologies in ways that do not put their existing businesses at risk, while newcomers may face fewer barriers to pursuing new technological opportunities.
\end{abstract}

\section{Keywords}

Brownfield, convergence, digitization, e-book, greenfield, institutional, entrepreneurs, publishing

\section{Suggested citation}

Hjarvard, S. and Helles, R. (2014), 'Going digital: Changing the game of Danish publishing', Northern Lights 13, pp. 49-64, doi: 10.1386/nl.13.49_1 


\section{Introduction}

Until recently, the spread of the e-book had been quite slow in Denmark as well as in other continental European countries and had not evoked major changes in the publishing industry - at least not compared to developments in the United States and United Kingdom (Wischenbart 2013; Colbjørnsen 2014). There may be several reasons for this 'delayed' adoption of e-books compared to the Anglo-American world, including the sizes of national languages, regulations on book markets, the type of dominant actors in the publishing field, etc. Several statistics regarding publishing, sales and reading of books seem, however, to indicate that the e-book has now reached the state of take-off (Hjarvard and Helles 2013). In the case of Denmark, the publishing of e-books is now expanding and is gradually becoming an important source of revenue for publishers. Digital publications' share of the Danish publishers' annual turnover rose from $12.0 \%$ in 2013 to $14.3 \%$ in 2014. Educational publishing is clearly leading the sale of digital materials, but, in trade book publishing, digital materials rose to $7.8 \%$ of the sales in 2014 (Forlæggerforeningen 2015). Digitization in general and the spread of the e-book in particular represent not only a technological shift from print to digital media but involve several substantial changes in the publishing industry as a whole - for instance, changing business models, new forms of distribution, and a potential shift in the very conception of 'the book'.

In this article, we will focus on the growing convergence between the traditional publishing industry and other media industries in light of the digitization process. The shift towards digital technologies has ushered a series of new actors into the publishing business, and many of these come from backgrounds in other media sectors - for instance, telecommunications, the music industry and web media. New business ventures not only bring new practices and interpretative frameworks to the world of book publishing, but existing players also begin hiring people with educational and professional backgrounds from outside of the traditional realm of literature and publishing: programmers, online community managers, big data analysts, etc.

Some consequences of digitization are often understood as instances of disintermediation (Lind 2002) - for example, the break-up of existing processes and removal of intermediaries within a particular business domain or cultural field. In the case of publishing, digital bookstores like Amazon may threaten the existing position of physical bookstores in the book's value chain, and various forms of digital self-publishing may similarly undermine the prominent position and gatekeeping function of existing publishing houses. Disintermediation is clearly a feature of ongoing transformations in the field of publishing (Phillips 2014), but we would like to emphasize an equally important aspect of these changes - namely, the convergence between the field of publishing and the broader field of media industries. Seen from within the field of publishing, developments may primarily be understood as a disruption of existing structures and practices due to changes ('threats') coming from outside, but, seen from a broader perspective, developments may instead be understood as a process of convergence or, to put it in the vocabulary of social science, an instance of institutional integration. From an institutional perspective, digitization comes to serve as a lever for a mediatization of the book (Hjarvard 2013), through which the field of publishing eventually accommodates to various logics from media industries and media use practices. 
Through these processes, publishing and book reading become gradually integrated into the broader media industry and consumption patterns of other media. The internal disruption of the publishing field is accompanied by a gradual integration into wider media culture.

From this overall perspective, we will consider the e-book as an organizational game changer in the publishing industry by looking at two particular changes resulting from the e-book: the emergence of new business models for digital distribution and sale of books as well as the entry of new types of actors with experiences from other institutional fields. More precisely, our enquiry is guided by the following two research questions:

- To what extent and in what ways are new practices and perceptions imported into the publishing field from other sectors (e.g. media businesses)?

- What are the similarities and differences between established actors in the publishing field and newcomers to the field? In particular, what are the limits and possibilities for these two types of actors to adapt to new business models in publishing?

Analysis of actors in the Danish book market must take into account the specific characteristics of this market as well as its regulatory and cultural context. Within the limited space of a journal article, it may suffice to say that the Danish trade book market is characterized by a low level of public regulation and subsidy. Since 2000, the book market has been subject to gradual deregulation, and from 2011 there have been no fixed prices on books. As a consequence, book sales are not limited to bookstores alone, and books may be sold like any other commodity - for instance, in supermarkets (Styrelsen for Bibliotek og Medier 2008; Konkurrence- og Forbrugerstyrelsen 2013). Similarly, there is no VAT exemption on books, and the Danish book market may be regarded as among the most liberal from a comparative European perspective (Rønning et al. 2012). The book market is not completely without public influence and regulation; in particular, public libraries play an important role in the publishing industry as both a major buyer of books and a display window for literature. Furthermore, public libraries have played an important role in introducing digital material to readers through services like eReolen and litteratursiden.dk. It is also important to remember the small scale of the publishing industry in Denmark: With fewer than 5.5 million native speakers, the Danish reading public is roughly the same size as the population of Berlin, Germany. As we will demonstrate, both old and new actors in Denmark may share common concerns about the potential influence of much larger global actors like Amazon and Apple.

\section{Theory}

Three conceptual frameworks inform our analysis: the concept of 'convergence' from media studies; the notion of 'institutional entrepreneurs' from institutional theory; and the distinction between 'brownfield' and 'greenfield' development from the management theory of infrastructural development. The concept of 'convergence' specifies how digital technologies bring together hitherto-distinct media: for instance, the smartphone combines on a single device digital versions of analogue-born media like radio, television, books 
and telephone as well as new digitally born media like e-mail and social network media. Convergence not only takes place at the technological level but may also occur at the level of content, generic convention, economics, industry, audience, etc. Henry Jenkins (2006) suggests that we should consider convergence from a holistic perspective in which the various levels of convergence interact with each other:

Some common ideas referenced by the term include the flow of content across multiple media platforms, the cooperation between multiple media industries, the search for new structures of media financing that fall at the interstices between old and new media, and the migratory behavior of media audiences who would go almost anywhere in search of the kind of entertainment experiences they want.

(Jenkins 2006: 282)

The convergence process is not universal, and, while convergence may take place at one level, divergence may occur at another. In their study of European publishing, Rønning and Slaatta (2011) consider mergers in the industry and observe an organizational streamlining in their wake. This does not, however, imply a general convergence at all levels: 'we are talking about organizational convergence, characterized by greater efficiency, optimization and cost control within the publishing unit, rather than technological convergence based on recycling, reuse and economies of scale within the entire group' (Rønning and Slaatta 2011: 1111; original emphasis). The tendency towards organizational and economic concentration in both publishing and media industries through buy-ups and mergers may still allow room for the relative autonomy of various publishing units, and new technologies allow new actors to enter the publishing field and thereby diversify output.

While organizational convergence may not necessarily or in the first instance affect the diversity of publishing units (e.g. editorial entities) or output (e.g. volume and type of books), technological convergence can as we will demonstrate in this study - involve the importing of skills and business models, which may in the long run affect the institutional logics of the field. In order to demonstrate this, we use the term 'institutional entrepreneurs' from institutional theory. From the so-called 'institutional logics' perspective (Thornton et al. 2012), we may regard culture and society as consisting of various institutional fields, each characterized by a particular set of governing logics. For instance, the field of publishing may be governed by a particular constellation of technological, political regulatory, commercial and cultural logics that have developed over time. Thompson (2010) develops a similar notion of the logic of the publishing field based on the sociology of Bourdieu.

Thornton (2004) uses this perspective to give a historical account of higher education publishing and stipulates a transition from one phase dominated by an editorial logic to another phase increasingly dominated by a market logic. Each of these phases is characterized by a particular organizational identity, legitimacy, authority structure, mission, focus of attention, etc. Institutional domains do not work in isolation; change is often instigated by institutional entrepreneurs who "creatively manipulate social relationships by importing and exporting cultural symbols and practices from one institutional order to another' (Thornton and Ocasio 2008: 115). For instance, publishing firms may 
begin hiring IT professionals in order to take advantage of new technologies, but such professionals bring with them values, work routines, and conceptions of media and audiences that may over time influence the publishing firm's operations.

Finally, we draw upon IT management consulting's vocabulary of infrastructural development to borrow the distinction between greenfield and brownfield technological development (Hopkins and Jenkins 2008). Greenfield development denotes development of new infrastructure in an area or sector where no existing infrastructure of any value is in place: The rolling out of mobile Internet coverage in Third World countries where no Internet infrastructure is in place is a typical example of greenfield development. The rolling out of mobile Internet coverage in areas with extensive WiFi network coverage (such as metropolitan areas in western cities) is, on the other hand, brownfield development due to the already developed nature of the infrastructure. The logic behind the distinction is that the presence or absence of functional infrastructure impacts the viability of business models based on the rolling out of new infrastructure: If a company already owns an existing infrastructure, the margins that can be obtained by establishing new and better infrastructure must be weighed against the losses in revenue on existing infrastructure. Similarly, the prospective competition and marketing costs differ substantially between greenfield and brownfield development.

The distinction between the two types of development is normally taken to be a straightforward matter of identifying the existing technological landscape in a given situation and then planning further development in accordance with the identified scenario: Greenfield and brownfield thus appear to be substantially rooted in an existing (technological) state of affairs. Yet for our investigation, we will use the distinction between the different scenarios to be at least as much a case of stakeholder perspective, in the sense that different actors evaluate the relative importance of different technological trends quite differently. As we shall demonstrate, different perspectives vis-à-vis technological developments appear to depend not only on how long actors have been in the field or their dependency on income through existing technological infrastructure but also on how they position their core, professional identity in relation to the traditional dichotomy between books as commodities or books as cultural artefacts.

\section{Method}

Our study is based on semi-structured interviews with key stakeholders in the Danish publishing and book distribution business. Our sample included both established market players, such as the largest Danish publishing house Gyldendal and the nationwide bookstore chain Arnold Busck, and new actors in the field such as Mofibo, an online book subscription service. The digital bookstore Saxo.com may be positioned in the middle, according to this parameter. Saxo.com has already become an established and dominant digital bookseller in the Danish market; yet it is still in the process of building up new digital businesses. Both new and old businesses come in affluent as well as financially struggling varieties: Some newcomers are professional companies looking to establish a profitable business in the book sector (sometimes high-tech start-ups), such as Liveboox, an online bookstore with digital books only, while others are more DIY-type businesses, comprising single authors 
or one-man publishing ventures such as Publizd.com, a non-profit portal for self-publishers and small publishing houses.

The sample was limited to private/commercial actors in the trade book market, and as such we excluded actors driven by pure enthusiasm on the one hand and producers of technical/educational literature on the other. This was not because such actors were deemed irrelevant as general sources on the transformation of the entire market for printed material but instead because we were interested in understanding the different positions that actors in a single market might take vis-à-vis each other. Within this (substantial) subsection of the book industry, we chose our sample as a maximum variation sample and aimed to cover as many different perspectives and positions as possible. In light of the relatively small amount of attention academic research has granted to the publishing sector in Denmark so far, our study aimed to uncover broad structures of convergence and divergence between different stakeholder perspectives. For this reason, the sample was not intended to reflect the current landscape of trade book publishers in the Danish market in its entirety but rather to enable us to investigate the central lines of tension in perspectives on publishing and digitization between stakeholders occupying as different positions in the market as possible.

The occasion for the interviews was framed as our broad interest in understanding the changing conditions for the publishing industry. The interviews were conducted as qualitative, semi-structured research interviews (Kvale 2007), each of 45-75 minutes' duration. Research assistant Marie Hemmingsen assisted with some of the interviews and the transcription of recordings. Analysis of the interviews followed a thematic-comparative approach based on the interview structure. The following people were interviewed:

Stig Andersen, Managing Director, Gyldendal. Gyldendal is the biggest publishing house in Denmark.

Anders Blauenfeldt, Director of Developments, Mofibo. Mofibo is an e-book online subscription service.

Morten Bracker, Founder and Head of Publizd.com. Publizd.com is a non-profit portal for books serving self-publishers and small publishing houses.

Christine Bødtcher-Hansen, Managing Director, Danish Publishers

Association.

Claus Dyre, Managing Director, Liveboox. Liveboox is an online bookstore with digital books only.

Helle Busck Fensvig, Managing Director, Arnold Busck. Arnold Busck is a major bookstore chain in Denmark.

Elisabeth Fogtdal Nøjgaard, Director of Legal and Political Affairs, Gyldendal. Gyldendal is the biggest publishing house in Denmark.

Jørgen Balle Olesen, Managing Director, Saxo.com A/S. Saxo.com is the biggest Danish online bookstore.

Andreas Nordkild Poulsen, Head of Communication, Arnold Busck. Arnold

Busck is a major bookstore chain in Denmark.

Hanne Salomonsen, Director of Gyldendal Academic. Gyldendal is the biggest publishing house in Denmark. 


\section{Between cathedral and market}

The publishing industry is often described as being caught in a tension between two opposite perspectives on book publishing, which can be seen either as a cathedral or as a market (e.g. Schiffrin 2010). The cathedral perspective points to the role of publishers as serving a higher calling as midwives to great literary artworks while the market perspective points to the necessity that publishers and booksellers (also) apply a commercial logic in conducting their trade. For established publishing houses, this polarity is often expressed as a balancing act of wins and losses across the spectrum of publications, where the occasional bestseller helps pay for the important (but not commercially viable) publication of narrower literature. This tension is not exclusive to the Danish publishing industry, but it is important to note that the small size of the language (and hence also the market) means that the commercial potential of even the strongest Danish-language bestsellers is marginal compared to that of world languages such as English and Spanish. Combined with the small literary circuit, even the largest actors in the Danish book market are marketing both narrow literature and (potentially) 'big books' (Thompson 2010). Indeed, the tension (sometimes between 'culture' and 'market') is recognized as relevant across all of our interviews, even if the positions of our respondents on the issue locate them in different parts of the spectrum.

The tension between the cathedral and the market has been a fact of life for generations of publishers and appears to remain a lived reality for our informants. Yet, contrary to their predecessors in the trade, our current interviewees also work in a period of rapid technological change within their industry, which affects all parts of the value chain of literary production and the book business. Similar to developments internationally, the Danish publishing industry has seen its chain of production shift from analogue to digital, just as the book market has been deregulated, as book prices are no longer fixed. Thus, even if the budding e-book market in Denmark is seen by many as the first sign of a digital shift in book production and circulation, the book business has already been under transformation for over a decade.

All of our respondents explicitly or implicitly find that developments over the last decade have generally moved the field of book publishing further away from the 'cathedral' and closer to the 'market', but this is not only or not primarily associated with the influence of the ongoing shift from analogue to digital publishing. For the established players in the business, the consequences of deregulation have been of more immediate concern over the last decade than the emergence of the e-book. The push towards commercialization is also related to the emergence of other analogue players and increased competition on the pricing of physical books. Asked about the most important changes in the book market, Helle Busck Fensvig, Managing Director of the Arnold Busck bookstore chain, points to the growing influence of a new type of book seller: 'The supermarkets have a prominent position in the book market, which they don't have in many of the countries we usually compare ourselves to'. One consequence of this, Helle Busck Fensvig states, is the growing difficulty of the non-bestselling novel, which receives insufficient exposure and sales.

In response to current developments, the Gyldendal publishing house announced in 2014 that it will 'listen more to the market' and, for instance, 
publish more lifestyle books. Managing Director Stig Andersen explains this rapprochement with the market to the trade journal Bogmarkedet: Gyldendal "has always been and is still "editorially driven" in contrast to "market-driven" where you give people what you think they want. All successful publishers have been "editorially driven", and we continue to be that of course, but we must see if we are able to mix the two things in a more clever way' (Larsen 2014). Similarly, the Managing Director of the Danish Publishers Association, Christine Bødtcher-Hansen, says in our interview that it has 'been very significant that the book has been subject to much stronger competition and is therefore also being perceived as much more equal to all other sorts of commodities'. As we shall consider in our analysis below, the deregulation of books and the process of making books more equal to other commodities are further strengthened with the introduction of new digital players to the book market.

\section{What the publishing business is about}

Established and dominant actors in the field, such as the publishing house Gyldendal and the bookstore chain Arnold Busck, convey a confident identity in which the content of books is at the centre of their business. For the publisher, this implies that the curating of authors and manuscripts, the editorial process, and the subsequent marketing of books and authors are considered the core of the business. For the bookstore, it means that the acquisition of books and ability to provide customers advice about books are considered of key importance. Both have a clear sense of ongoing changes and have for several years engaged in various digital projects to develop their businesses. In general, they consider these developments as extensions of their existing business in which the physical book is being supplemented by a digital counterpart. This is reflected in the phrase that the e-book is basically a digital file ('a PDF') of the printed book. A major objective for the established actors is therefore to consider how new digital projects may develop without jeopardizing existing businesses and how to maintain the firm's existing focus and identity. Helle Busck Fensvig, Managing Director of Arnold Busck, states that 'it goes without saying that a bookstore with a reputation of having personnel who know the books, have read the books, and therefore know what they are talking about and live for selling books, would never launch a service if the sole purpose was not to sell books'.

The digital newcomers to the business also have an exclusive focus on books: The companies Liveboox, Publizd.com and Saxo.com do not have activities in other media businesses, and, although the founder of Mofibo is involved in other high-tech businesses, Mofibo itself only focuses on books. The newcomers do, however, convey a rather different understanding of their identity and business. This becomes very clear when they talk about the qualifications they look for when hiring new people and when they characterize their main competitors. Anders Blauenfeldt, Mofibo's director of development, who himself has a background in the telecommunications sector, states that his company is very IT driven and that this influences the kind of people they hire:

It's really difficult to find programmers with experience from the publishing business [...] It would of course be great to employ people who'd created book apps before, but I've just hired a skilled Apple developer who's made music apps. So [we hire] people with content experience, 
but whether you come from music, film, or other places is less important as long as you know how to build a perfect interface for a content service and can get the integration with Facebook to work and so on. We're a bit conscious that it's okay - and our role - to look at the publishing business with fresh eyes.

Jørgen Balle Olsen, Managing Director of Saxo.com and with a personal background from a family-owned bookstore, gives a somewhat similar account of the skills needed in his business: 'If there's one thing we don't recruit, it's people with a background in the publishing industry [...] Many of the people we hire today are entrepreneurial types, often people with other projects and activities on the side, people we know we won't be able to keep for a long time, but their bandwidth is just five times bigger than traditional employees'. Managing Director Claus Dyre from Liveboox, who himself has a background in marketing and construction, also points to other digital media in order to describe the idea of his business: Whereas he describes a digital bookstore such as Saxo.com as a 'bookstore 1.0', he characterizes Liveboox as the next step: 'I consider us as a bookstore 2.0: We bring new types of reading experiences to the users. Of course, we need to be good at managing the platform we use. We use IT, and we use the newest tools to exploit the IT possibilities'.

The newcomers in the book industry look not only for skills, experience and inspiration from other digital media but also consider other media as their main competitors. Jørgen Balle Olesen from Saxo.com says, 'It's not Arnold Busck or Indeks Retail [a major wholesale company in the Danish book market; authors' remark] that are our main competitors today. It's Amazon, it's Apple, it's Google. This is where the battle will be fought'. A very similar line of reasoning is expressed by Anders Blauenfeldt from Mofibo, who says, 'Our main competitors aren't Saxo or the book-app from Gyldendal. Our competitors are Netflix and Facebook and whatever else might distract the attention of the customer, for instance the icon on your smartphone just beside the Mofibo app'. From the point of view of the newcomers, book publishing is about the provision of content that competes for attention in a market of content and services from many other media, and in order to enable a viable business you need to import and adapt to skills, practices and perceptions prevailing within this broader media field.

This understanding of the business of books is clearly distinct from the ideas prevalent among the traditional actors. The latter not only have their identity firmly anchored to the book as a particular type of artefact and content but also consider changes in terms of how these changes impact the internal competition between various actors in the book market. Established companies are focusing on the competition between books, whereas newcomers are just as concerned with the competition between books and other media. Not all digital newcomers, however, share this perception. The non-profit company Publizd.com is primarily rooted within the world of publishing, and its managing director Morten Bracker is himself an author. From his perspective, digital technologies and the e-book may enable authors to circumvent the traditional publishers and marketing channels and reach their readership in new ways. According to him, the liberalization of the book market has made the established publishers focus on bestsellers, and digital book solutions may be a means of allowing more voices to be heard. In his own self-understanding, Publizd.com is truer to the cultural values of book publishing than are the 
established actors in the field; yet he simultaneously borrows ideas from the world of Internet media concerning a non-profit cultural commons that enable individual authors and readers to meet without the need for commercial intermediaries.

\section{The role of the reader}

Established actors like Gyldendal and Arnold Busck try to balance cultural concerns with market considerations. Arnold Busck is seeking to exhibit a wide range of books catering to many different tastes, and Gyldendal owns numerous imprints in addition to its own quality brand, allowing it to diversify its publishing activities. In terms of readership, they attempt to strike a balance between two perceptions of the role of the reader as a cultural citizen and as a private customer. Due to commercial pressure, the balance is tipping towards the private customer, but this move towards the market is done somewhat reluctantly because it is at odds with the established actors' self-perception. Stig Andersen from Gyldendal provides an example of such reluctant marketization by emphasizing Gyldendal's hesitation to publish the erotic novel Fifty Shades of Grey (Danish edition 2012, E. L. James): 'Gyldendal represents quality and diversity, and there were many discussions - internal as well as external - about us publishing Fifty Shades of Grey. But we are happy that we did because it's earned us a lot of money'.

Several of the digital newcomers do not share this hesitation but instead have a much more explicit commercial strategy, targeting the mainstream market in which cultural considerations play a marginal role, if any. Anders Blauenfeldt from Mofibo states this very clearly:

We're targeting the mass market or the wide segment. This is not to say that we're targeting everything. We're actually quite specific in our segmentation: We don't want to be the service for heavy users, book nerds, and MAs in comparative literature. We try to communicate with and be a service for those who read one or two books a month or less.

This strategy is also a reflection of the economic rationality of Mofibo's online subscription model: Income is based on customers signing up for a monthly subscription, but the more books that an individual customer reads, the more expensive the customer is for Mofibo.

The orientation towards the customer or consumer is clearly driven by a business interest, but it is also stimulated by the fact that the newcomers have experiences from other media businesses in which data about audiences are much more readily available and frequently used for developing and optimizing production and sale. The reading of e-books via streaming services allows the company to acquire and utilize information about readers in new ways. As Anders Blauenfeldt from Mofibo puts it bluntly, 'After we've been working for one year, we're now starting to have more data available about reading behavior than the publishers have had during their entire 250 years of existence.

We're very conscious that such data represents value'. For the digital bookstore Saxo.com, the ability to generate big data about reader behaviour also presents an important change in the relationship to customers at the same time as it may prompt a significant shift in the very basis for selling books. Jørgen Balle Olesen from Saxo.com states, 
One thing's for sure. When things become digitized, the marginal costs become close to zero, so in the long run there's no one who'll earn a living by selling books. Things will move in the direction of Spotify and Netflix, that is, 'all you can eat' models, which then become the commodity. Then, where's the value? It could be the business intelligence area.

That will become one of the values.

Neither Saxo.com nor Mofibo has thus far managed to utilize business intelligence about digital reading to any significant degree, but this perception of the value of the audience differs significantly from the mindset of the established actors in the field. The latter, however, are also beginning to take an interest in this form of business intelligence, both directly through their own digital activities and indirectly by dealing with customers like Mofibo and Saxo.com. In this way, new perceptions of readers may gradually become more widespread as they become embedded in the information resources on which business decisions are based.

Readers may also come to represent value in another way, as suggested by Morten Bracker from Publizd.com. His non-profit project seeks to increase the visibility and credibility of self-publishers and smaller publishing firms in the digital environment. With little or no money for marketing books, selfpublishers and smaller publishing houses need to join forces, Morten Bracker argues, and displaying book titles together in the same portal is one means of creating synergy and attracting traffic. But visibility alone does not do the trick. In the online world of plentitude, the problem for readers is not just navigating and discovering potentially interesting titles but also deciding which ones to choose. Here, the recommendations and reviews of other book readers become important as has generally been the case with many other commodities sold on the Internet. Where Anders Blauenfeldt from Mofibo focuses on the value of information about reader behaviour, Morten Bracker from Publizd. com highlights the value of readers writing reviews: 'I think reviews will be a very strong currency in the future. If you visit a website and look at two books, one without reviews and one with a couple of reviews, then you'll go for the one with reviews'.

Whether you are in the book market with the primary purpose of doing business, as in the case of Mofibo, or instead wish to help smaller authors and publishers become visible in the market from non-profit motives, as in the case of Publizd.com, the digital entrepreneurs bring with them an emphasis on the importance of the reader in their construction of the business. By comparison, the established actors in the field are to some extent influenced by a production perspective on book publishing: They are particularly concerned with the acquisition and subsequent selling of authors and books. The new actors in the field are to a greater extent informed by a consumer or reader perspective on the book: their point of departure is the value of reader attention and interest in books, not necessarily for the readers' own sake or interest but because digital media carry with them a logic emphasizing user engagement and allow for continuous data on user behaviour. 


\section{Greenfields and brownfields}

Both new and established actors in the field acknowledge that their ability to adapt to and take advantage of the changing environment is unequally distributed. As Stig Andersen from Gyldendal says, 'When you're a company like Gyldendal, you need to constantly consider the various [distribution] channels, whereas new players in the market can just go ahead and really don't have anything they need to protect'. Claus Dyre from Liveboox similarly argues that the established publishers

know the digitization train is running, and they want to be on that train as well, but the question is when you should jump on the new train. It has to be done at the right moment. You can't just drop the 80-90\% of the income [from existing activities]. It's therefore much easier for the new actors.

This classic dilemma between new and old actors during times of technological change may be interpreted through the notions of brownfield and greenfield developments. At present, the market for digital books in Denmark is - to some extent - a greenfield in which technological solutions, business models, organizational structures and user preferences are still in the making. The brownfield of the well-established paper book market is to some extent an important resource for the established players to enter the greenfield of digital publishing, but it also represents a problem since initiatives in the digital area must not severely jeopardize the print area. This is an important factor for several reasons, as comes across very clearly in our interviews and discussions concerning the pricing of e-books. Established actors again and again emphasize that the idea of dumping the price on e-books is very dangerous for several reasons: Cheaper e-books will tend to lower the prices on paper books as well, and the Danish book market is in any case too small to allow for the prices you find on e-books in the Anglo-American market.

The aversion of established publishers to embrace the potentially much lower marginal costs of e-book circulation not only hinges upon the potential revenues of books to be published in the future: the valuation of publishing houses ultimately rests upon the intellectual rights of the back catalogue owned by the corporation. If market prices on books were to drop significantly, this would affect not only future earnings but also the very value of the companies themselves. The newcomers seem less concerned with these problems, instead emphasizing that the (low) price is a fact in the online world and that their various business models are attempts to construct new models for book pricing - for example, subscribing to books instead of buying them. The different approaches to book pricing and selling not only provide a concrete example of the economic realities underlying the distinction between greenfield and brownfield development strategies but they also point to the interwoven nature of cultural and economic values in the book business.

The importance of past investments is also evident in the relationship between brownfield and greenfield operators among book distributors, which roughly equals the difference between traditional brick-and-mortar booksellers and online bookshops. In the interview with leading figures from the bookshop chain Arnold Busck, they describe elements of a future in 
which digital possibilities are closely linked with the development of physical bookshops. Helle Busck Fensvig says, 'We see our business as omni-channel. Customers should experience the physical and the digital bookshops as the same thing. What we think we can provide online [compared to onlineonly bookshops, $\mathrm{SH} \& \mathrm{RH}]$ is the human touch because our employees can provide expertise'. In addition to insisting that staff members must be able to communicate with customers via social media, an important element in the development of the services offered is to make online and offline parts of the business fit as closely together as possible. An example is the unification of customer experience through a unified payment flow between online and offline purchases. Andreas Nordkild Poulsen from Arnold Busck says, 'You should be able to exchange a book bought in our online shop in any one of our 30 physical shops. That's probably something that would make customers choose us. That's the kind of thing that needs to be done'. The underlying concern within these interview quotes is the importance of doing what one does best, which is providing added value in the form of expert advice and seamless services to customers.

A very different view of the role of physical bookshops is expressed in our interview with the owner of Saxo.com, Jørgen Balle Olsen. While the central business model of Saxo.com is the provision of books via online sales and, for e-books, via download, he also points to the possibilities for omni-channel delivery to include physical sales. Jørgen Balle Olsen says,

The physical sector [...] is under pressure, and I think they'll run into big problems. [...] But establishing the right cross-channel relationship might help. [...] It might be online booksellers moving into the physical shops, which would become delivery points. You go to the shop and look at their offerings, and if they don't have what you want, they can order it for you in the shop.

However, it is clear from the interview that these are relief measures and not something he considers a viable, long-term solution for bookstores. The physical shops should instead be thought of as one instrument among several that can be used to provide books to customers:

Yes, well, the general trend is that, since so much business moves online, the physical shops will get a new role. I think we'll see fewer wellestablished shops in the future but more pop-up shops. We all know that a lot of the trade volume in book sales is in the months before Christmas, so you could imagine temporary shops established at that exact time - when people are looking to buy books. So the structure of the business will adapt to new circumstances.

It is important to stress that the distinction between brownfield and greenfield is relative, and, considered in a global context, the digital entrepreneurs in the small Danish market are to some extent operating in a brownfield as well. Many of the important aspects of digital publishing and reading are already established facts in the sense that technological choices, business models, and conventions of user behaviour have already been implemented elsewhere in the world and in adjacent media industries in Denmark. For Mofibo and Liveboox, the recent spread of tablet computers in Denmark is a sine qua non for the success of their businesses, and their perceptions of possibilities in this 
greenfield are highly influenced by the business models and experiences of companies such as Amazon, Netflix and Spotify. Danish digital entrepreneurs may thus have some leeway to experiment, but our interviews also reflect that experimentation in this greenfield is informed by imitation or the borrowing of experiences from a global brownfield of digital publishing as well as a Danish brownfield of other digital media industries - for example, the experience of music industry digitization.

The global context is not merely important as a source of new technological standards and business models. In a small market such as the Danish one, all players are aware that market conditions may be subject to rapid change if actors such as Amazon should decide to enter the market. This is a real threat for both old and new players, and it already has consequences, even if the market has hitherto been considered too small to be of interest to global players. The prospect of losing their investments due to the arrival of much larger players makes Danish companies hesitant. In the words of Christine BødtcherHansen, Managing Director of the Danish Publishers Association, 'When you have the threat of a big global player, many don't dare plunge into something new because they'll lose their investment the moment the big player arrives. It's an unfortunate but very real consideration'.

\section{Conclusion}

The changing technological landscape of the book business means that our informants not only share an orientation on the axis between cathedral and market but can also be organized according to their views on the scope and nature of these changes. Even if some of the issues on this second axis are only implicitly present in our informants' statements, we include them here as major elements that help us make sense of the reasons and rationales characterizing the field of book publishing and trade today.

The differences between the various participants in our study can be broadly summarized as displayed in Figure 1. Both axes point to important distinctions between how the various types of actors approach the changes to the book business. The distinction between market and cathedral has been with the book business for many years, but developments in relation to the liberalization of the Danish book market, changes to modes of online sales and distribution as well as (digital) production have forced actors to reorient themselves. This has made the 'market' pole on the axis more relevant. In one sense, some of the new actors on the publishing side can be said to have taken over the more purist notion of market-free book production for the sole sake of literature; yet the cathedral dimension clearly remains a relevant point of orientation even for established publishers.

The distinction between greenfield (evolutionary) and brownfield (foundational) attitudes towards new developments also informs the views of our interviewees. The interviews explicitly reflect this distinction in relation to the perceived importance of the pricing of e-books and the relevance of physical book shops. In a broader sense, the distinction also informs our interviews in the willingness with which actors located differently along the axis adopt business models and institutional logics from other fields of business - in particular, from other parts of the media sector. 


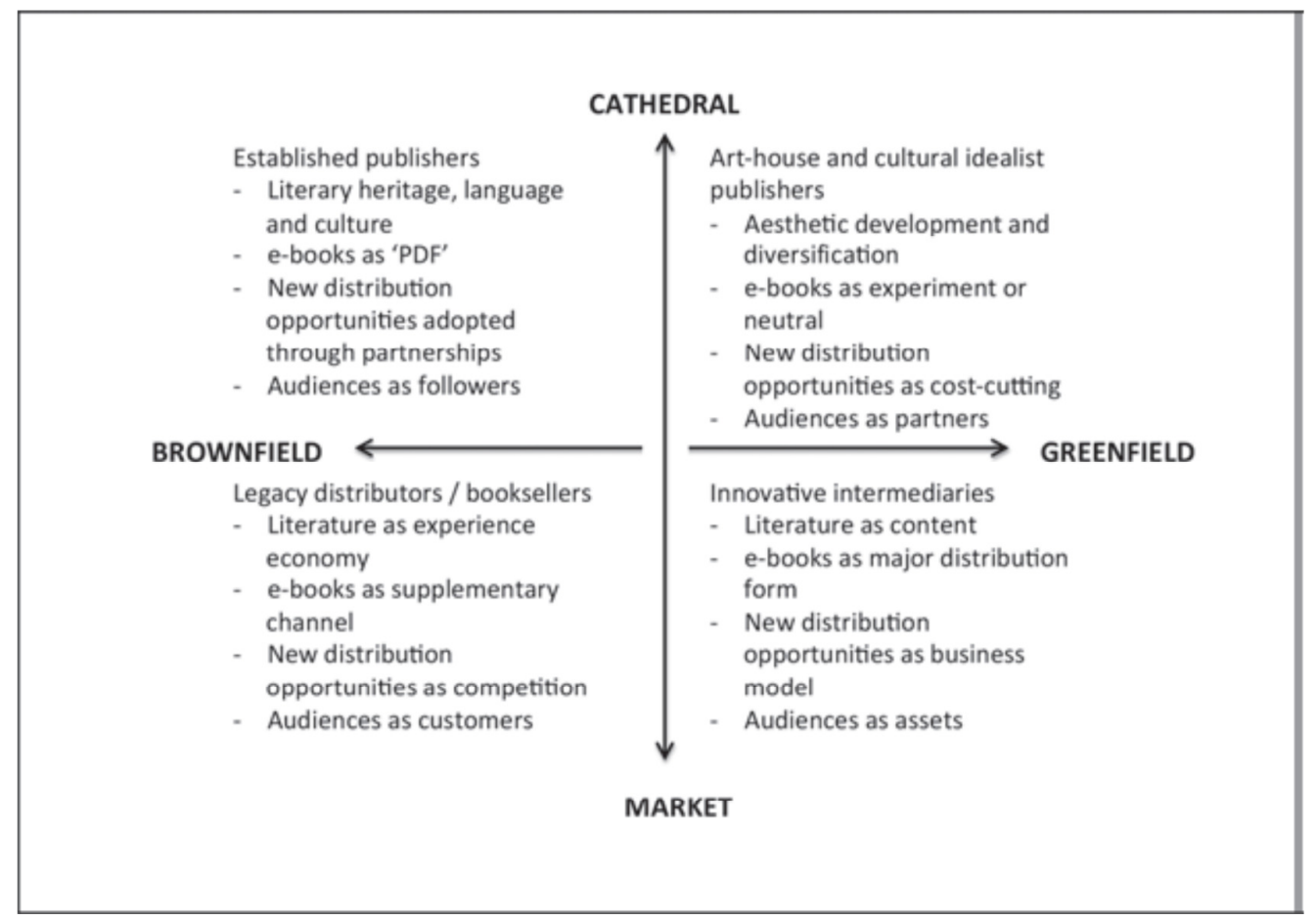

Figure 1: Orientations of different actors in the Danish book business.

In addition to exposing the institutional logics applied by actors from across the field, our study also points towards the highly inter-related nature of the system of business logic, literary values and technological developments that characterizes the digitization of the book business in Denmark. Gaining a more detailed understanding of the interplay between these aspects for the different types of players in the field represents an important area for future research.

\section{References}

Colbjørnsen, T. (2014), 'Continuity in change. Case studies of digitalization and innovation in the Norwegian book industry 2008-12', Ph.D. dissertation, Oslo: Oslo University.

Forlæggerforeningen (2015), Årsstatistik 2014/'Yearly statistics 2014', Copenhagen: Danish Publishers' Association, http://www.danskeforlag. dk/download/pdf/033aiak999_Forl\%C3\%A6ggerforeningens_\%C3\%85rss tatistik_2014.pdf. Accessed 25 March 2015.

Hjarvard, S. (2013), The Mediatization of Culture and Society, London:

Routledge.

Hjarvard, S. and Helles, R. (2013), 'Digital books on the point of take-off? The Ebook in Denmark Anno 2013', Academic Quarter, 07, Fall, pp. 34-50, http:// www.akademiskkvarter.hum.aau.dk/pdf/vol7/2a_SHjarvardRHelles_ DigitalBooks.pdf. Accessed 24 March 2015.

Hopkins, R. and Jenkins, K. (2008), Eating the IT Elephant: Moving from Greenfield Development to Brownfield, Indianapolis: IBM Press book. Jenkins, H. (2006), Convergence Culture. Where Old and New Media Collide, New York: New York University Press.

Konkurrence- og Forbrugerstyrelsen (2013), Liberaliseringen af bogmarkede. 
En evaluering set med forbrugernes фjne/'Liberalization of the book market. An evaluation seen from the consumers' point of view', Copenhagen:

Konkurrence- og Forbrugersstyrelsen, https://www.kfst.dk/ /media/

KFST/Publikationer/Dansk/2013/20131113\%20Liberaliseringen\%20af\%20

bogmarkedet\%20nov.pdf. Accessed 26 June 2015.

Kvale, S. (2007), Doing Interviews, London: Sage.

Larsen, B. (2014), 'Gyldendals direktør: "Vi vil lytte mere til markedet"'/

'Gyldendal's Managing Director: "we will listen more to the market",

Bogmarkedet, 15 September. http://bogmarkedet.dk/artikel/gyldendalsdirekt\%

C3\%B8r-vi-vil-lytte-mere-til-markedet. Accessed 25 July 2015.

Lind, R. A. (2002), 'Disintermediation', in S. Jones (ed.), Encyclopedia of New

Media: An Essential Reference to Communication and Technology, London:

Sage, pp. 150-51.

Phillips, A. (2014), Turning the Page. The Evolution of the Book, London:

Routledge.

Rønning, H. and Slaatta, T. (2011), 'Marketers, publishers, editors: Trends in international publishing', Media, Culture \& Society, 33:7, pp. 1109-20.

Rønning, H., Slaatta, T., Torvund, O., Larsen, H. and Colbjørnsen, T. (2012), Til bokas pris. Utredning av litteraturpolitiske virkemidler $i$ Europa/'The price of the book: Report on literary policy instruments in Europe', Oslo: Kulturdepartementet og Kunnskapsdepartementet, https://www.regjeringen. no/globalassets/upload/kd/hoeringsdok/2012/201201052/til_bokas_ pris_utredning_av_litteraturpolitiske_virkemidler_i_europa.pdf. Accessed 26 March 2015.

Schiffrin, A. (2010), Words \& Money, London: Verso.

Styrelsen for Bibliotek og Medier (2008), Rapport fra bogudvalget 20072008/'Report from the book committee 2007-2008', Copenhagen: Styrelsen

for Bibliotek og Medier, http://www.bs.dk/publikationer/rapporter_andre/ bogudvalg/pdf/Rapport_fra_bogudvalget.pdf. Accessed 25 June 2015.

Thompson, J. B. (2010), Merchants of Culture. The Publishing Business in the Twenty-First Century, Cambridge: Polity.

Thornton, P. H. (2004), Markets from Culture. Institutional Logics and Organizational Decisions in Higher Education Publishing, Stanford: Stanford University Press.

Thornton, P. H. and Ocasio, W. (2008), 'Institutional logics', in R. Greenwood (ed.), The SAGE Handbook of Organizational Institutionalism, Los Angeles: SAGE, pp. 99-129.

Thornton, P. H., Ocasio, W. and Lounsbury, M. (2012), The Institutional Logics

Perspective. A New Approach to Culture, Structure and Process, Oxford: Oxford University Press.

Wischenbart, R. (2013), Global eBook. A Report of Market Trends and Developments, Vienna: Rüdiger Wischenbart Content and Consulting.

\section{Contributor details}

Stig Hjarvard is Professor of Media Studies and Vice-Chair at the Department of Media, Cognition and Communication, University of Copenhagen. His research interests include journalism, media and globalization, digital books, media and religion and mediatization theory. He is Chair of the Book and Literature Panel of the Danish Ministry of Culture. He is Chief Editor of the journals Northern Lights (Intellect Press) and Journal of Media, Cognition and Communication (Royal Danish Library). His most recent book in English is The 
Mediatization of Culture and Society (Routledge, 2013). Further info: http://mcc.ku.dk/staff/?pure=en/persons/87296

Contact: University of Copenhagen, Department of Media, Cognition and Communication, Karen Blixens Vej 4, 2300 Copenhagen S, Denmark.

E-mail: stig@hum.ku.dk

Rasmus Helles is Associate Professor of Media Studies at the Department of Media, Cognition and Communication, University of Copenhagen. His research interests include digital media and communication, media sociology with a special focus on digital media, media policy and regulation, empirical methodologies, and theory of science. He has published in journals like International

Journal of Communication, New Media and Society, First Monday, and Policy \& Internet. Further info: http://mcc.ku.dk/staff/?pure=en/persons/149580

Contact: University of Copenhagen, Department of Media, Cognition and Communication, Karen Blixens Vej 4, 2300 Copenhagen S, Denmark.

E-mail: rashel@hum.ku.dk

Stig Hjarvard and Rasmus Helles have asserted their right under the Copyright, Designs and Patents Act, 1988, to be identified as the authors of this work in the format that was submitted to Intellect Ltd. 